Relations industrielles

Industrial Relations

\title{
Redesigning Work: A Blueprint for Canada's Future Well-being and Prosperity, By Graham Lowe and Frank Graves (2016), Toronto, Canada: University of Toronto Press, 273 pages. ISBN: 978-1-4426-4445-8
}

\section{Gordon B. Cooke}

Volume 72, numéro 4, automne 2017

URI : https://id.erudit.org/iderudit/1043177ar

DOI : https://doi.org/10.7202/1043177ar

Aller au sommaire du numéro

Éditeur(s)

Département des relations industrielles de l’Université Laval

ISSN

0034-379X (imprimé)

1703-8138 (numérique)

Découvrir la revue

Citer ce compte rendu

Cooke, G. B. (2017). Compte rendu de [Redesigning Work: A Blueprint for Canada's Future Well-being and Prosperity, By Graham Lowe and Frank Graves (2016), Toronto, Canada: University of Toronto Press, 273 pages. ISBN:

978-1-4426-4445-8]. Relations industrielles / Industrial Relations, 72(4), 808-809. https://doi.org/10.7202/1043177ar

Tous droits réservés (C Département des relations industrielles de l’Université Laval, 2017
Ce document est protégé par la loi sur le droit d'auteur. L'utilisation des services d'Érudit (y compris la reproduction) est assujettie à sa politique d'utilisation que vous pouvez consulter en ligne.

https://apropos.erudit.org/fr/usagers/politique-dutilisation/ 


\section{Recensions / Book Reviews}

\section{Redesigning Work: A Blueprint for Canada's Future Well-being and Prosperity}

By Graham Lowe and Frank Graves (2016), Toronto, Canada: University of Toronto Press, 273 pages. ISBN: 978-1-4426-4445-8.

Graham Lowe is Professor Emeritus at University of Alberta, and President of The Graham Lowe Group Inc. Frank Graves is the Founder of EKOS Research Associates, and is a Fellow of the Marketing Research and Intelligence Association. Both of these authors have many years of experience studying the complexities of the Canadian labour market, including the analyses of survey and other quantitative data pertaining to the employment realities facing Canadians.

The authors seem to have three objectives that they hope to achieve by disseminating this book. First, by accessing substantial numbers of detailed workplace/workforce and public opinion surveys, the authors seek to document the various ways in which the world of world is changing, and how those changes are affecting Canadian workers, individually and collectively. Second, since the net effect of those changes is negative at an aggregate level, the authors propose a set of public policy solutions that could be undertaken to respond to, or even attempt to counter, those work changes. This leads to the third, and key, objective of the authors. They state, in explicit terms, that their main goal is to "make a better working future for all Canadians" (Lowe and Graves, 2016: ix). This is a somewhat unusual admission, but it is a message that emerges consistently throughout the book. That is, the authors write the book from the perspective that there are disturbing trends affecting swaths of Canadian workers, and the authors are interested in solving/reversing the problems much more than (merely) documenting those trends.

Not surprisingly, given those three objectives, the first half of the book outlines the way that the designs of jobs and types of jobs, and forms of paid work generally, have changed. Put bluntly, the situation is ominous for many Canadian workers who sense that their opportunities are shrinking and declining in quality. Many Canadians can articulate problematic aspects of the job that they hold, and of the organization in which they work. From several different angles, the authors establish that Canadians are feeling less secure, less content, and less valued by their employer than in the past, on average, when looking at aspects like work schedules, flexibility, tasks, pay, benefits, security, and the chance to train/advance.

But, because of the quality of the EKOS Survey data (accumulated over 15 years) that they accessed, the authors also layer on demographic differences, individual preferences, and financial situations to explain how it is an oversimplification to categorize jobs (or other paid work opportunities) as being inherently good or bad for an average individual. Rather, the more important and complicated issue is the extent to which individuals are able to acquire and retain work opportunities that are sufficiently appealing to themselves in terms of duties, schedules, remuneration, involvement, and fit with other aspects of life. Lowe and Graves explore how certain job or organizational characteristics tend to be positive or negative for an average worker, but then "drill down" to show how combinations of job and organizational components can be desirable or undesirable to different types of individuals. For instance, job security might be less important to university-educated workers (who probably can demand and get a permanent job) compared to high schooleducated workers trying to find (any) stable employment. Looked at another way, when it comes to the issue as to whether a job is desirable, it is in the eye of the beholder, and not simply to be judged by some supposedly objective criteria. The quality and depth of analysis that the authors undertake (to establish the conditions workers are facing) is highly impressive and convincing. 
I found the book to be much more provocative once the authors toggled from analyzing the work opinions of Canadian to proposing policy remedies that individual employers in Canada should be taking. It is certainly accurate that Canadian citizens have more education than ever before, on average, and yet a vast number are underemployed either in terms of the number of hours that they desire, being in a lower paid job than they desire, or being unable to use all of their skills and abilities on the job. Needless to say it is probable that many face all three of these problems. Certainly, at a collective level, that presumably translates into a gap in terms of Canadian competitiveness, lost economic output, and potentially most importantly, reduced well-being, job satisfaction, and economic security among Canadian workers. Those are serious shortcomings. But, it is a leap when Lowe and Graves advocate that individual employers are, or should be, obligated to provide opportunities for their employees to be able to use all of their skills, to develop new ones, and to have a chance at advancement. This is perfectly plausible for large, resourcerich, white-collar organizations with job ladders (to facilitate career advancement), especially those without a profit motive or facing global competition (such as public sector employers). Nevertheless, what about the millions of Canadian workers employed in small and medium sized enterprises with limited resources (and profit margins), and who have basic tasks that need to be undertaken cheaply? This is not a criticism of the book or authors, per se. Rather, my point is that the first half of the book makes the convincing case that employment conditions are deteriorating for that (Canadian) workers, and the second half of the book is more controversial because the authors, to their credit, provide several specific policy recommendations for readers to contemplate.

If a person cannot find the type of work that they find fulfilling, should that obligate an employer to alter job design to suit the worker? Suppose a retailer or hospitality provider needs a couple of seasonal workers to top up staff levels at peak times on evenings and weekends during busy periods. Is that employer, or should the employer be obligated to change the assigned duties, job direction, work schedule, or number of scheduled weekly hours to enrich the job? I would argue that the employer has every right to design the job to suit operational and strategic objectives, and, then, to advertise it to see if (sufficiently) attractive applicants are interested in the opportunity. The theme throughout the book is that Lowe and Graves encourage (Canadian) employers to aim higher by addressing the financial needs (in terms of security, pay, and benefits) and psychological needs of workers (in terms of involvement, new challenges, job enrichment, participation in decision-making, and job security, and general well-being), rather than designing jobs to satisfy operational purposes. Whether employers are obligated to do so is a debate worth having, because there are plausible policy alternatives. However, one thing is beyond dispute. If more employers committed to that ideal, the world of work would be a better place. I think that this readable, yet weighty, book should be of interest to academics, human resource professionals, and public policy decision-makers. Personally, I will be introducing some of these concepts from the book into future industrial relations courses for students to ponder.

\section{Gordon B. Cooke}

Associate Professor, Industrial Relations

Faculty of Business Administration

Memorial University of Newfoundland

\section{Income Inequality: \\ The Canadian Story}

Edited by David A. Green, W. Craig Riddell and France St.-Hillaire (2016) Montreal: Institute for Research on Public Policy/ Institut de recherche en politiques publiques (IRPP), 558 pages. ISBN: 978-0886-4532-99.

Inequality has been a major theme in debates over economic performance and 